\title{
Glucose excretion by the symbiotic Chlorella of Spongilla fluviatilis
}

\author{
Andrea Fischer, Doris Meindl, and Eckhard Loos * \\ Lehrstuhl für Zellbiologie und Pflanzenphysiologie, Universität Regensburg, Universitätsstrasse 31, D)-8400 Regensburg. \\ Federal Republic of Germany
}

\begin{abstract}
Chlorella sorokiniana strain 211-40c, a symbiotic Chlorella isolated from a freshwater sponge, excreted between $3 \%$ and $5 \%$ of assimilated ${ }^{14} \mathrm{CO}_{2}$ as glucose in the light, with a $\mathrm{pH}$ optimum around 5 . This percentage increased when the illuminance was lowered (to $15 \%$ at $200 \mathrm{~lx}$ ). Release of $\left[{ }^{14} \mathrm{C}\right]$ glucose continued in the dark and could be inhibited by the uncoupler carbonyl cyanide $p$-trifluoromethoxyphenylhydrazone (FCCP). Net efflux of glucose occurred even at a concentration ratio of extracellular/intracellular glucose of 4. This, together with the sensitivity to FCCP, is taken as evidence for active transport. Exogenous $\left[{ }^{14} \mathrm{C}\right]$ glucose was taken up by the cells under conditions of net glucose efflux, showing uptake and excretion to take place simultaneously.
\end{abstract}

Key words: Chlorella (symbiosis) - Glucose excretion (Chlorella, symbiosis) - Symbiosis

\section{Introduction}

Chlorococcal algae occur frequently in freshwater symbiotic systems and several physiological studies have been made on these symbionts, especially on the maltose-excreting Chlorellae from green $\mathrm{Hydra}$ and from Paramecium bursaria (see Reißer and Wießner 1984). Little information is available on the glucose excretion of the algal partner in the sponge-Chlorella association (Muscatine et al. 1967; Wilkinson 1980). The goal of the present work was to investigate parameters influencing this sugar excretion, and the results indicate that it occurs by active transport.

\footnotetext{
* To whom correspondence should be addressed
}

Abbreviations: $\mathrm{FCCP}=$ carbonyl cyanide $p$-trifluoromethexyphenylhydrazone; p.c. $=$ packed cells

\begin{abstract}
Material and methods
Plant material. Chlorella sorokiniana Shihira el Krauss strain $21140 \mathrm{c}$, the endosymbiont from Spongilla flutiatilis, was obtained from Sammlung für Algenkulturen. (jöttingen, FR(;. The alga was grown at $28^{\circ} \mathrm{C}$ in $1-1$ glass tubes $(6.5 \mathrm{~cm}$ diameter in the medium described by Kuhl (1962), which was bubbled with a $2 \%\left(\mathrm{CO}_{2}\right.$-air mixture. (ontinuous light of $5700 \mathrm{~lx}$ was provided by fluoreseent tubes. The alga grew with a minimal doubling time of $6.4 \mathrm{~h}$. Cultures were harvested after $47 \mathrm{~d}$ when they had reached a cell density in the range of $1.0 \quad 3.0 \mu$ l packed cells (p.c.) $\cdot \mathrm{ml}{ }^{\prime}$. (ells were suspended in $50 \mathrm{mM}$ citric acid-trisodium citrate buffer pll 5.1 at a cell density of $4 \mu \mathrm{l}$ p.c. $\cdot \mathrm{ml}^{\prime}$.
\end{abstract}

Incuhation of Chlorella with ${ }^{1+4} \mathrm{CO}_{2}$. For fixation of ${ }^{14} \mathrm{CO}_{2}$. $0.5 \mathrm{ml}$ of algal suspension was pipetted into a cylindrical glass vial (approx. $5 \mathrm{ml}$ total volume) provided with a small well attached to the inside containing $30 \mathrm{\mu l} \mathrm{Ba}^{14} \mathrm{CO}_{3}$ suspension corresponding to $12.8 \mathrm{kBq}$ and $1.73 \mu \mathrm{mol} \mathrm{C}^{\left(\mathrm{C}_{2}\right.}$. The vial was closed with a rubber stopper and ${ }^{14} \mathrm{CO}_{2}$ wass liberated by injecting an excess of half-concentrated phosphoric acid into the side well; the final $\left(\mathrm{O}_{2}\right.$ concentration in the gas phase then was approx. $0.9 \%$ by volume. Up to six such vials could be lined up in a waterbath thermostated at $28^{\circ}$ ('; they were shaken in a circular fashion at $210 \mathrm{rpm}$. Illumination was provided by spotlights and amounted to $15000 \mathrm{~lx}$ unless indicated otherwise. Different illuminances were achieved by calibrated wire screens mounted in front of the vessels. The incubation time was $1 \mathrm{~h}$ unless indicated otherwise.

Estimation of ${ }^{14} \mathrm{C}$ incorporation and excretion: analysis of excretion products. At the end of the incubation period the cells were separated from the medium by filtration or centrifugation. Incorporated radioactivity was determined in a scintillation counter after the eells had been hydrolyzed by stirring for $2 \mathrm{~h}$ in trifluoroacetic acid $(2 \mathrm{M})$ at $120^{\circ} \mathrm{C}$. For analysis of excreted substances the medium was acidified with acetic acid. evaporated to dryness under reduced pressure and redissolved in $1 \mathrm{ml}$ $\mathrm{H}_{2} \mathrm{O}$; an aliquot was counted as above. (harged compounds were removed by the mixed ion-exchange resins Serdolit CS-2 $\left(\mathrm{H}^{+}\right.$-form) and $\mathrm{AS}-6$ ( $\mathrm{HCO}_{3}$-form) from Serva. Heidelberg. FRG. Thin-layer-chromatographic analysis of the desalted medium was made on silica-gel-coated aluminum sheets (Merck. Darmstadt. FR(j) employing the solvent system acetone: $n$-butanol: $\mathrm{H}_{2} \mathrm{O}=70: 15: 15$ (by vol.). Radioactive spots were detected with a thin-layer chromatography (TLC) analyzer LB 


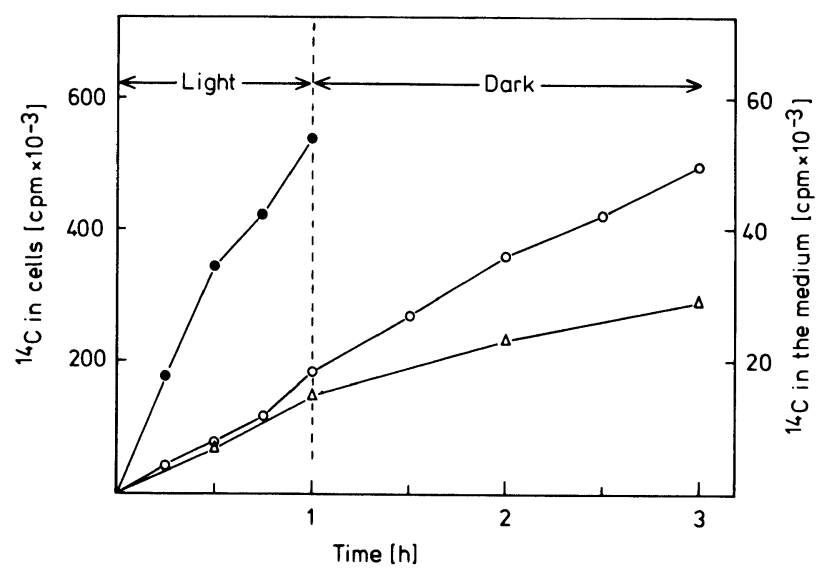

Fig. 1. Kinetics of ${ }^{14} \mathrm{C}$-labelling of cells and of excretion products of symbiotic Chlorella sorokiniana 211-40c. $\bullet \bullet \bullet$, radioactivity in cells; $O_{-}-0$, total radioactivity in the medium; $\triangle-\Delta$, radioactivity of uncharged material in the medium. The rate of ${ }^{14} \mathrm{CO}_{2}$ fixation was $700 \mu \mathrm{mol} \cdot \mathrm{h}^{-1} \cdot(\mathrm{ml} \mathrm{p.c.)})^{-1}$. After the light period, one sample was centrifuged, the cells were resuspended in fresh buffer, transferred into a darkened vial with air as gas phase and were shaken. Every half hour the medium was removed for counting and was replaced by fresh buffer; the cumulated counts were plotted in the graph

284 from Berthold, Wildbad, FRG. The radioactivity of a peak was calculated from its percentage of the sum of all peak areas and from the total radioactivity applied to the TLC sheet.

Determination of intra- and extracellular glucose concentrations. The algae were separated from the medium by vacuum filtration and extracellular glucose was determined in the filtrate using the hexokinase/glucose-6-phosphate dehydrogenase system (Bergmeyer et al. 1974). To obtain intracellular glucose, watersoluble compounds were extracted from the cells in principle according to Bieleski (1982). For this purpose the cells were transferred into a $-20^{\circ} \mathrm{C}$ cold mixture of $\mathrm{CH}_{3} \mathrm{OH}: \mathrm{CHCl}_{3}$ : $\mathrm{H}_{2} \mathrm{O}: \mathrm{HCOOH}=12: 5: 2: 1$ (by vol.), incubated overnight at $-20^{\circ} \mathrm{C}$, and $\mathrm{CHCl}_{3}$ and $\mathrm{H}_{2} \mathrm{O}$ were added to give a ratio $\mathrm{CHCl}_{3}: \mathrm{CH}_{3} \mathrm{OH}: \mathrm{H}_{2} \mathrm{O}: \mathrm{HCOOH}=18: 12: 5: 1$ (by vol.). After shaking and phase separation at room temperature the aqueous phase was withdrawn and concentrated under reduced pressure. Turbidities were removed by centrifugation and, after adjusting the $\mathrm{pH}$, glucose was determined enzymatically as above. The yield of extraction was determined by adding a known amount of carrier-free $\left[{ }^{14} \mathrm{C}\right]$ glucose to the initial extraction mixture and by counting an aliquot at the end of the procedure; yields were between $70 \%$ and $80 \%$. Checks were made for the efficiency of the enzymatic glucose assay in the presence of the cell extract by adding standard amounts of glucose at the end of the assay. The cell volume was calculated by subtracting from the packed cell volume the volume of intercellular water which was considered as the space accessible to soluble starch, a polymer not hydrolyzed by Chlorella sorokiniana 211-40c (Reißer 1984; Douglas and Huss 1986). For this purpose the concentration of soluble starch was determined in the filtrate of a suspension with $300 \mu \mathrm{l}$ p.c. $\mathrm{ml}^{-1}$ and in a control without cells by measuring the absorption of the iodine-starch complex at $540 \mathrm{~nm}$.

\section{Results}

Fixation of ${ }^{14} \mathrm{CO}_{2}$; excretion and analysis of labeled products. Assimilation of $\mathrm{CO}_{2}$ by Chlorella was lin-
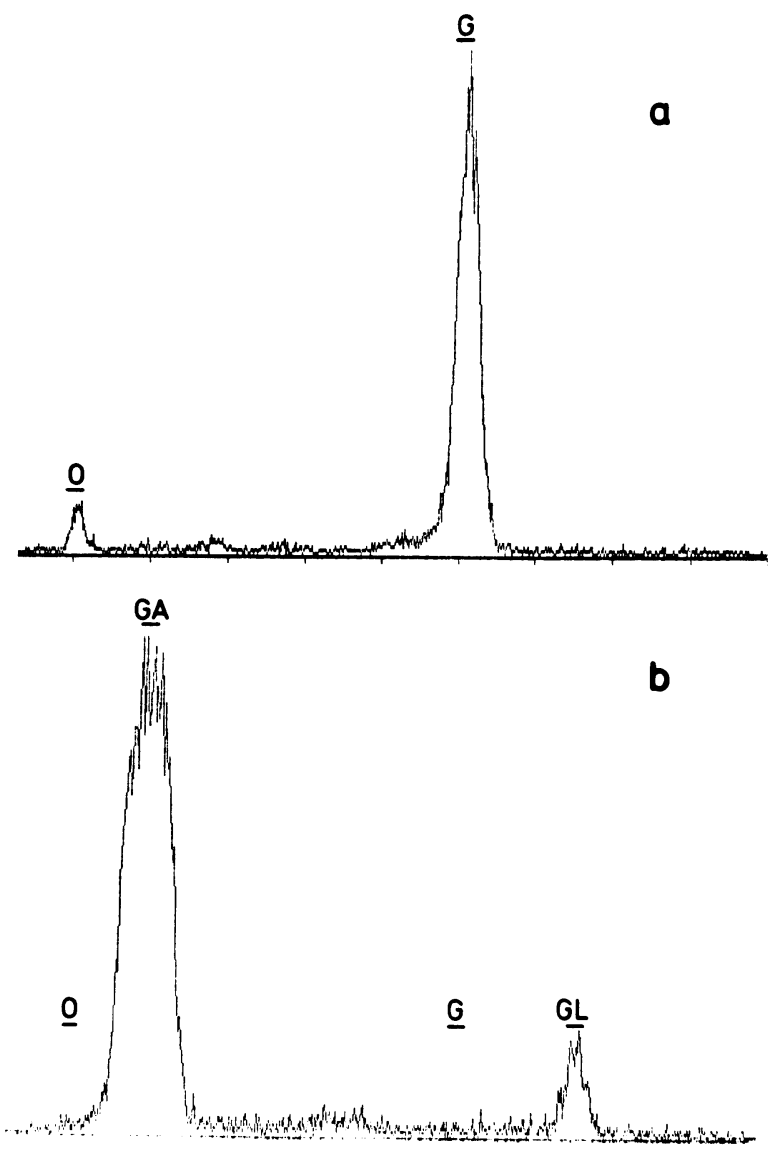

Fig. 2 a, b. Scans for radioactivity of thin layer chromatograms. a Excretion products of Chlorella sorokiniana 211-40c at pH 5.1; the medium was treated with mixed ion-exchange resins before separation (see methods). b Analysis of the peak at the position of glucose in a. The peak material was eluted and incubated in a total volume of $0.55 \mathrm{ml} 18 \mathrm{mM} \mathrm{Na}$-acetate buffer pH 5.6 with $25 \mathrm{U}$ glucose oxidase (Boehringer, Mannheim, $\mathrm{FRG}$ ) for $30 \mathrm{~min}$ at $30^{\circ} \mathrm{C}$, treated with cation exchanger (Serdolit CS-2, $\mathrm{H}^{+}$-form, Serva, Heidelberg, FRG) and was chromatographed. The positions of reference substances are indicated : $G=$ glucose; $G A=$ gluconic acid $G L=$ gluconolactone; $O=$ origin

ear for at least $1 \mathrm{~h}$ and was paralleled by an excretion of labeled material (Fig. 1). In several experiments, between $3 \%$ and $5 \%$ of the total fixed ${ }^{14} \mathrm{C}$ was excreted. Upon darkening the excretion continued and, after $2 \mathrm{~h}$ in darkness, had reached a value of about $10 \%$.

Most of the radioactive material in the medium did not bind to the ion exchangers (Fig. 1) and was hence uncharged. Thin-layer-chromatographic analysis revealed one predominant peak at the position of glucose (Fig. 2a). When this peak was eluted, treated with glucose oxidase and rechromatographed, two peaks appeared at the position of gluconic acid and gluconolactone, respectively (Fig. 2b). This is evidence for glucose as the major 


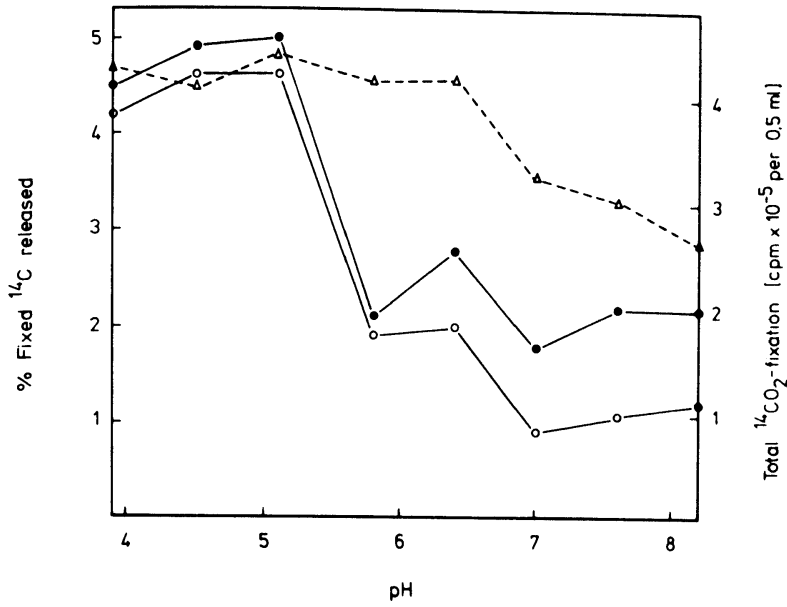

Fig. 3. Dependence on $\mathrm{pH}$ of total ${ }^{14} \mathrm{CO}_{2}$ fixation by cells of Chlorella sorokiniana 211-40c and of excretion of labeled products. - - overall excretion; $0-0$, glucose excretion; $\Delta^{---} \Delta$, total ${ }^{14} \mathrm{CO}_{2}$ fixation. The buffers used were citric acidtrisodium citrate $(\mathrm{pH} 3.9-5.1), 2-(\mathrm{N}$-morpholino)ethanesulfonic acid- $\mathrm{NaOH}$ (pH 5.8 and 6.4) and 4-(2-hydroxyethyl)-1-piperazineethanesulfonic acid- $\mathrm{NaOH}(\mathrm{pH} 7.0-8.2), 50 \mathrm{mM}$ each. The absolute value of $\mathrm{CO}_{2}$ fixation at $\mathrm{pH} 5.1$ was $45.5 \mu \mathrm{mol} \cdot \mathrm{h}^{-1}$. (mg chlorophyll) $^{-1}$

excretion product of the Spongilla endosymbiont, confirming the observations of Muscatine et al. (1967) and Wilkinson (1980).

Parameters influencing glucose excretion. Figure 3 illustrates the dependence on $\mathrm{pH}$ of overall excretion and of glucose excretion in the light, expressed as percent of total fixed ${ }^{14} \mathrm{C}$. Overall excretion and glucose excretion were high around $\mathrm{pH} 5$ but displayed a pronounced drop towards the neutral and alkaline range; here, additional unidentified peaks appeared upon thin-layer chromatography. Fixation of ${ }^{14} \mathrm{CO}_{2}$ was relatively constant between pH 3.9 and 6.4 and declined somewhat towards higher $\mathrm{pH}$ values (Fig. 3, dashed line). No significant effect of the ions $\mathrm{K}^{+}$and $\mathrm{Ca}^{2+}$ (tested at concentrations of $10^{-2} \mathrm{M}$ and $10^{-4} \mathrm{M}$ ) could be found in a single experiment.

The amount of $\left[{ }^{14} \mathrm{C}\right]$ glucose excreted during $1 \mathrm{~h}$ of ${ }^{14} \mathrm{CO}_{2}$ assimilation rose with increasing illuminance, up to $900 \mathrm{~lx}$, and then stayed fairly constant (Fig. 4, curve $\mathrm{A}$ ); ${ }^{14} \mathrm{CO}_{2}$ fixation, however, increased up to $15000 \mathrm{~lx}$ (Fig. 4, curve B). The percentage of fixed ${ }^{14} \mathrm{C}$ released as glucose, therefore, rose towards lower illuminances (Fig. 4, curve C). Up to $15 \%$ of the assimilated ${ }^{14} \mathrm{C}$ was transferred out of the algal cells as glucose at $200 \mathrm{~lx}$.

The temperature optimum for $\left[{ }^{14} \mathrm{C}\right]$ glucose excretion in the light was at $28^{\circ} \mathrm{C}$, that for ${ }^{14} \mathrm{CO}_{2}$ assimilation at $32^{\circ} \mathrm{C}$ (data not shown).

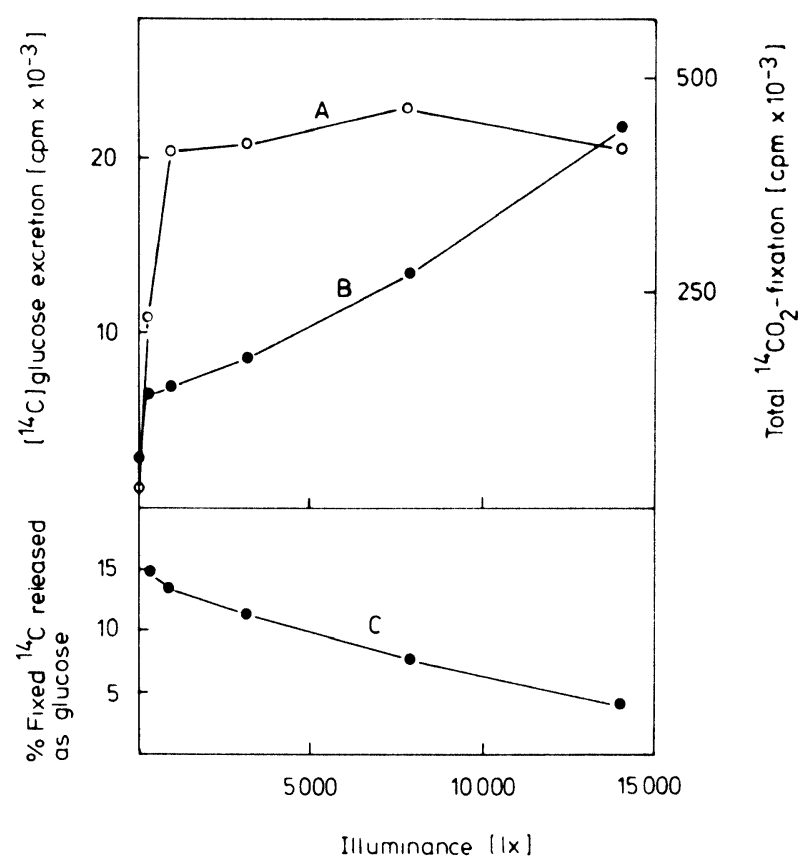

Fig. 4. Fixation of ${ }^{14} \mathrm{CO}_{2}$ and $\left[{ }^{14} \mathrm{C}\right]$ glucose excretion by cells of Chlorella sorokiniana $211-40 \mathrm{c}$ in the light as a function of light intensity. A. excreted labeled glucose; $\left.B \cdot{ }^{14} \mathrm{C}^{\mathrm{C}}\right)_{2}$ fixation: $C$, percentage of fixed ${ }^{14} C$ released as glucose

Evidence for active export of glucose. One piece of evidence for an energy-requiring step in glucose excretion should be its sensitivity to uncouplers like FCCP. After assimilation of ${ }^{14} \mathrm{CO}_{2}$ in the light the efflux of $\left[{ }^{14} \mathrm{C}\right]$ glucose in the dark was found to be inhibited by FCCP (Fig. 5). Provided the formation of glucose from precursors (e.g. polysaccharides/sugar phosphates) is energy-independent, these experiments indicate glucose excretion to be an energy-consuming process, or, more strictly, to require intact $\mathrm{pH}$ gradients.

An essential criterion for active transport of a sugar is its net movement against a concentration gradient (Komor 1982). To obtain information on this type of transport, the concentration of the glucose appearing in the medium was determined at different times and compared with the intracellular glucose concentration. At the start of the experiment the medium was made $1.5 \mathrm{mM}$ with respect to D-glucose to shorten the time for the build-up of a convincing glucose gradient outside/inside. Glucose was assayed enzymatically; labelling via ${ }^{14} \mathrm{CO}_{2}$ and simple radioactivity determinations were not employed, since the specific activities of internal and excreted glucose might well change in the time course of the experiment. Table 1 shows that there was an increase in external glucose concentration from $1.37 \mathrm{mM}$ to $2.42 \mathrm{mM}$ within $2.5 \mathrm{~h}$. 


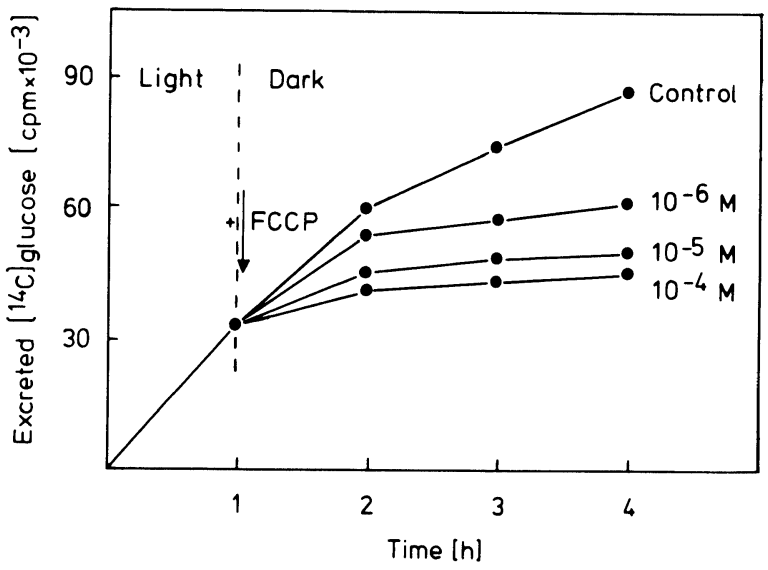

Fig. 5. The effect of FCCP on $\left[{ }^{14} \mathrm{C}\right]$ glucose excretion by cells of Chlorella sorokiniana 211-40c in the dark. In a 25-ml Erlenmeyer flask, $5 \mathrm{ml}$ of algal suspension $\left(2 \mu \mathrm{l} \mathrm{p.c.} \cdot \mathrm{ml}^{-1}\right.$ in $50 \mathrm{mM}$ citric acid-trisodium citrate buffer $\mathrm{pH}$ 5.1) were shaken in the light $(15000 \mathrm{~lx})$ in an atmosphere containing $0.8 \% \mathrm{CO}_{2}$ by volume with a specific radioactivity of $7.4 \mathrm{kBq} \cdot \mu \mathrm{mol}^{-1}$. After $1 \mathrm{~h}$ the cells were transferred to a darkened flask, the residual ${ }^{14} \mathrm{CO}_{2}$ was removed by a vigorous stream of air and FCCP was added in ethanolic solution; a corresponding amount of ethanol was added to the control. After different times, aliquots were removed and the amount of labelled glucose in the medium was determined
Table 1. Time course of changes in intra- and extracellular glucose concentrations in a cell suspension of Chlorella sorokiniana 211-40c. Algae were suspended at a cell density of $100 \mu \mathrm{l}$ p.c. $\mathrm{ml}^{-1}$ in $30 \mathrm{ml} 50 \mathrm{mM}$ citric acid-trisodium citrate buffer $\mathrm{pH} 5.1$ containing $1.5 \mathrm{mM}$ glucose and were shaken at $260 \mathrm{rpm}$ in a $500-\mathrm{ml}$ Erlenmeyer flask which was continously gassed with $2 \%(\mathrm{v} / \mathrm{v}) \mathrm{CO}_{2}$ in air. Illumination was $15000 \mathrm{~lx}$ and the temperature $28^{\circ} \mathrm{C}$. After different times 4-ml aliquots of the suspension medium were withdrawn, vacuum-filtrated on $0.45-\mu \mathrm{m}$ cellulose-nitrate membrane filters $(5 \mathrm{~cm}$ diameter) and washed twice with $1 \mathrm{ml}$ citrate buffer. Extracellular glucose was assayed enzymatically in aliquots from the filtrate, and intracellular glucose in algal extracts obtained according to Bieleski (1982; see Material and methods). Intracellular concentrations are corrected for intercellular water content of packed cells

\begin{tabular}{rlll}
\hline $\begin{array}{r}\text { Time } \\
(\mathrm{min})\end{array}$ & \multicolumn{2}{l}{ Glucose concentration $(\mathrm{mM})$} & $\begin{array}{l}\text { Concentration } \\
\text { ratio } \\
\text { outside/inside }\end{array}$ \\
\cline { 2 - 3 } & Intracellular & Extracellular & \\
\hline 0 & 0.345 & 1.37 & 4.0 \\
30 & 0.385 & 1.49 & 3.9 \\
60 & 0.405 & 1.74 & 4.3 \\
90 & 0.440 & 1.93 & 4.4 \\
120 & 0.506 & 2.13 & 4.2 \\
150 & 0.625 & 2.42 & 3.9 \\
\hline
\end{tabular}

Table 2. Time course of radioactivity and glucose concentration in the medium and of glucose uptake and excretion by cells of Chlorella sorokiniana 211-40c. In a 100-ml Erlenmeyer flask, $10 \mathrm{ml}$ of algal suspension were incubated under conditions as described in the legend to Table 1 . At time zero, $18.5 \mathrm{kBq}$ carrier-free $\left[{ }^{14} \mathrm{C}\right]$ glucose were added. Samples of the medium were obtained at the indicated times by vacuum filtration and used for liquid scintillation counting and enzymatic glucose determination (see Material and methods). For calculation of glucose uptake the average specific radioactivity of each time interval was used

\begin{tabular}{|c|c|c|c|c|c|c|}
\hline \multirow{2}{*}{$\begin{array}{l}\text { Time } \\
(\min )\end{array}$} & \multirow{2}{*}{$\begin{array}{l}\text { Radioactivity } \\
\text { in the medium } \\
\left(\mathrm{cpm} \cdot(50 \mu \mathrm{l})^{-1}\right)\end{array}$} & \multirow{2}{*}{$\begin{array}{l}\text { Glucose } \\
\text { concentration } \\
\text { in the medium } \\
(\mathrm{mM})\end{array}$} & \multirow{2}{*}{$\begin{array}{l}\text { Specific } \\
\text { activity } \\
(\mathrm{cpm} \cdot \mu \mathrm{mol})^{-1}\end{array}$} & $\begin{array}{l}\text { Glucose } \\
\text { uptake }\end{array}$ & $\begin{array}{l}\text { Net glucose } \\
\text { excretion }\end{array}$ & $\begin{array}{l}\text { Total glucose } \\
\text { excretion }\end{array}$ \\
\hline & & & & \multicolumn{3}{|c|}{$\left(\mu \mathrm{mol} \cdot(\mathrm{ml} \text { p.c. })^{-1}\right.$ per time interval $)$} \\
\hline 0 & 5388 & 1.54 & 69974 & & & \\
\hline 15 & 3995 & 1.46 & 54726 & 4.02 & -0.72 & 3.30 \\
\hline 30 & 3120 & 1.42 & 43943 & 3.19 & -0.36 & 2.83 \\
\hline 60 & 2877 & 1.95 & 29507 & 1.19 & 4.77 & 5.96 \\
\hline 90 & 2705 & 2.55 & 21215 & 1.22 & 5.40 & 6.62 \\
\hline 120 & 2461 & 3.26 & 15098 & 2.42 & 6.39 & 8.81 \\
\hline
\end{tabular}

Inside the cells the concentration rose from $0.35 \mathrm{mM}$ to $0.63 \mathrm{mM}$. Thus, net movement of glucose out of the cells occurred despite a concentration ratio outside/inside of 4 . This indicates an active export of glucose; furthermore, the linear kinetics of efflux precludes a diffusion-dependent equilibration whose rate should decline with time.

Uptake of glucose. Since most cells are able to take up glucose, this was presumed to occur also in the symbiotic Chlorella, a paradoxical situation which would mean real glucose excretion to be higher than the observed net efflux. When the alga were incubated in the presence of $\left[{ }^{14} \mathrm{C}\right]$ glucose, the radioactivity in the medium decreased and after a 30-min lag the glucose concentration in the medium increased (Table 2). This shows uptake and excretion of glucose to occur simultaneously. After $2 \mathrm{~h}$ the incorporated $\left[{ }^{14} \mathrm{C}\right]$ glucose could be recovered largely (53-70\%) as material insoluble in $80 \%$ ethanol, probably starch, since upon hydrolysis and analysis by thin-layer chromatography a prominent peak appeared at the position of glucose (data not shown). 


\section{Discussion}

One important characteristic of glucose excretion from the Spongilla symbiont is its $\mathrm{pH}$-dependence, with high rates in the acidic range ( $\mathrm{pH} 3.9$ to 5.1). This has been found also for maltose excretion from other symbiotic algae (Muscatine 1965; Muscatine et al. 1967) and, therefore, could indicate a similar export mechanism for these carbohydrates. Overall excretion from the Spongilla symbiont is less pH-dependent (Muscatine et al. 1967; Wilkinson 1980), since additional substances are excreted at higher $\mathrm{pH}$ values. The percentage of total fixed ${ }^{14} \mathrm{C}$ appearing as glucose in the medium amounted to only $3 \%-5 \%$, which agrees well with the literature (Muscatine et al. 1967). This figure rose to a value of up to $15 \%$, however, at low illuminances (Fig. 4). Such a light-dependent increase, though from $67 \%$ to $97 \%$, was also observed by Reißer (1987) for maltose excretion in a Paramecium symbiont, whereas the symbiont from Hydra, independent of the light level, released about $10 \%$ of the fixed ${ }^{14} \mathrm{C}$ into the medium (Cernichiari et al. 1969). This discrepant behaviour may be explained by assuming different saturation characteristics of photosynthesis and of sugar efflux in each organism.

The fourfold accumulation of glucose outside versus inside the cell is taken as evidence for an energy-requiring export process (Table 1). Whereas the determination of glucose in the medium is relatively easy and reliable, that of intracellular glucose is a more difficult task and is a critical point. For this reason checks were made during the course of the extraction procedure for losses of glucose and for eventual interferences of the cell extract with the glucose assay (see under Material and methods). The internal glucose concentration ideally should be known for the relevant cell compartment, in this case for the cytoplasm. If it comprises less than one quarter of the overall cell volume and if all cellular glucose is located there, glucose could have left the cell down a concentration gradient, e.g. by catalyzed diffusion, without the requirement of an active transport process. This possibility cannot be excluded as yet; also the effect of the uncoupler FCCP (Fig. 5) is basicall consistent with such a notion.

Some evidence for active sugar export from a Chlorella symbiotic with Paramecium has been presented by Zieseniß (1982). He showed maltose excretion to be inhibited by vanadate and diethylstilbestrol, these compounds presumably acting on a plasmalemma ATPase; he also mentioned that no change occurred in the intracellular maltose con- centration when high external levels of maltose were provided. Thus, active excretion of carbohydrate has to be considered for at least two symbiotic Chlorellae.

The rates of net glucose excretion (3.2 $11.8 \mu \mathrm{mol} \cdot \mathrm{h}^{-1} \cdot(\mathrm{ml} \text { p.c. })^{-1}$ in six experiments $)$ were relatively low when compared with glucoseuptake systems of other chlorococcal algae (100 $250 \mu \mathrm{mol} \cdot \mathrm{h}^{-1} \cdot(\mathrm{g} \mathrm{FW})^{-1}$; Komor 1982). For a closer comparison, data are still lacking on the glucose-export system, e.g. with respect to intracellular $\mathrm{pH}, \mathrm{K}_{\mathrm{m}}$ and $\mathrm{V}_{\max }$. Besides glucose excretion, concomitant uptake of that sugar has been found, though (except for an initial phase) at a lower rate (Table 2). In nature, however, uptake may prevail during prolonged dark phases and may be essential for heterotrophic nutrition of the alga. Such a role for a glucose uptake ability has been suggested for other symbiotic Chlorella strains (McAuley 1986).

This work was supported by the Deutsche Forschungsgemeinschaft. Thanks are due to Dr. W. Lockau, Institut für Botanik. Universität Regensburg, FRG, for critical reading of the manuscript.

\section{References}

Bergmeyer, H.U., Bernt, E., Schmidt, F., Stork, H. (1974) DGlucose: Bestimmung mit Hexokinase und (jlucose-6-phosphate-Dehydrogenase. In: Methoden der enzymatischen Analyse, vol. II. pp. 1241 1246, Bergmeyer, H.U., ed. Verlag Chemic, Weinheim

Bieleski, R.L. (1982) Sugar alcohols. In: Encyclopedia of plant physiology, N.S., vol. $13 \mathrm{~A}$ : Plant carbohydrates I. pp. 158 192, Loewus, F.A., Tanner, W., eds. Springer. Berlin Heidelberg New York

Cernichiari, E., Muscatine, L., Smith, D.C. (1969) Maltose excretion by the symbiotic algae of $H_{y} d r a$ viridis. Proc. $\mathrm{R}$. Soc. London Ser. B 173, 557576

Douglas, A.E., Huss, V.A.R. (1986) On the characteristics and taxonomic position of symbiotic Chlorella. Arch. Microbiol. 145,8084

Komor, E. (1982) Transport of sugar. In : Encyclopedia of plant physiology, N. S., vol. $13 \mathrm{~A}$ : Plant carbohydrates I. pp. 6.35 676, Locwus, F.A., Tanner, W., eds. Springer, Berlin Heidelberg New York

Kuhl, A. (1962) Zur Physiologie der Speicherung kondensierter anorganischer Phosphate in (hlorella. In: Beiträge zur Physiologie und Morphologie der Algen, pp. 157 166. Deutsche Botanische Gesellschaft, ed. Fischer, Stuttgart

McAuley, P.J. (1986) Glucose uptake by symbiotic Chlorella in the green-hydra symbiosis. Planta 168, 523529

Muscatine, L. (1965) Symbiosis of hydra and algae. III. Extracellular products of the algae. Comp. Biochem. Physiol. 16. 77.92

Muscatine, L., Karakashian, S.J., Karakashian. M.W. (1967) Soluble intracellular products of algae symbiontic with a ciliate, a sponge and a mutant hydra. Comp. Biochem. Physiol. 20, 112

Reißer, W. (1984) The taxonomy of green algae endosymbiotic in ciliates and a sponge. Br. Phycol. J. 19, 309318 
Reißer, W., Wießner, W. (1984) Autotrophic eukaryotic freshwater symbionts. In: Encyclopedia of plant physiology, N.S., vol. 17: Cellular interactions, pp. 59-74, Linskens, H.F., Heslop Harrison, J., eds. Springer, Berlin Heidelberg New York

Reißer, W. (1987) studies on the ecophysiology of endocytobiotic associations of ciliates and algae. II. Potential features of adaptation of symbiotic and free-living Chlorella spp. to the endocytobiotic habitat formed by Paramecium bursaria. Endocyt. Cell Res. 4, 317-329
Wilkinson, C.R. (1980) Nutrient translocation from green algal symbionts to the freshwater sponge Ephydatia fluviatilis. Hydrobiologia 75, 241-250

Zieseniß, E. (1982) Symbiose-spezifische Synthese und Exkretion von Maltose durch Chlorella spec. aus Paramecium bursaria. Dissertation, Göttingen

Received 15 December 1988; accepted 19 April 1989 